\title{
MENGEMBANGKAN PEMIKIRAN HAKIM DALAM MENYELESAIKAN SENGKETA
}

\author{
Soehartono \\ Fakultas Hukum Universitas Sebelas Maret Surakarta \\ e-mail : soehartonouns@yahoo.co.id
}

\begin{abstract}
This research reveal the rule of the judge, is specialy concening of inposed. whether or not the judge settled the dispute based on only the law (legislative product) or also based on non-written law living within the sociaty. This study was sociological research or empirical law research. The data employed was primary and also secondary as supporting data. The data collection was done using interview and library methods. The data was analyzed qualitatively. Based on the result of research and data analysis, it could be concluded that the judge in sentencing and settling dispute not always based on the written law or act only as a legislative product. In sentecing and setting dispute, the judge also relied on nonwritten law (considering the local wisdom). The judge did not only relied on logic and law stipulation, but as the law and justice enforcer, the judge also relied on the empathy and feeling. The judge did not only used IQ intellectuality but also EQ and SQ ones.
\end{abstract}

Keyword : judge verdict, dispute, conscience.

\begin{abstract}
Abstrak
Penelitian ini ingin mengkaji tentang peran hakim, khusunya dalam menjatuhkan putusan terhadap sengketa yang diajukan kepada. Apakah dalam menyelesaikan sengketa hanya berdasarkan pada undang-undang (produk legislatif) atau juga berdasarkan pada hukum yang tidak tertulis yang hidup dalam masyarakat. Penelitian ini bersifat sosiologis atau penelitian hukum yang bersifat empiris. Data yang dipergunakan adalah data primer, juga data sekunder sebagai pendukung. Pengumpulan data dilakukan dengan metode wawancara, juga dengan studi kepustakaan. Analisis data bersifat kualitatif. Berdasarkan hasil penelitian dan analisis data, dapat disimpulkan bahwa hakim dalam memutus dan menyelesaikan sengketa tidak selamanya hanya berdasarkan pada hukum tertulis atau undang-undang sebagai produk legislatif. Dalam memutus dan menyelesaikan sengketa hakim juga mendasarkan pada hukum tidak tertulis (memperhatikan kearifan lokal). Hakim tidak hanya mendasarkan pada logika dan ketentuan undang-undang, namun sebagai penegak hukum dan keadilan, hakim dalam memutus dan menyelesaikan sengketa juga mendasarkan pada empaty dan juga perasaan. Tidak hanya menggunakan kecerdasan Iq, tetapi juga eq dan Sq.
\end{abstract}

Kata kunci: putusan hakim, sengketa, hati-nurani.

\section{A. Pendahuluan}

Pada hakikat sebagai tugas pokok hakim dalam menjalankan tugasnya adalah untuk mengadili dan menyelesaikan perkara yang diajukan kepadanya dengan seadil-adilnya menurut hukum dan tidak membeda-bedakan orang (lihat Pasal 4 ayat (1) UU Nomor 48 Tahun 2009). Hakim sebagai salah satu pelaksana kekuasaan kehakiman mempunyai tugas pokok, yaitu sebagai penegak hukum dan keadilan. Tugas tersebut tidak mudah sebagaimana dibayangkan, karena dalam perjalanan waktu dan kenyataan tugas hakim yang diwujudkan dalam bentuk putusan yang dijatuhkan atau diambil tidak lepas dari kritikan dan hujatan yang sangat pedas.
Putusan hakim yang telah didasarkan kepada peraturan perundang-undangan, ternyata juga tidak dapat terlepas dari kritikan, hal demikian memang dapat terjadi karena undang-undangnya sendiri sudah tidak sesuai dengan keadaan dan situasi dan perkembangan dalam masyarakat, atau undang-undang tersebut sudah usang/ketinggalan jaman, tidak dapat mengakomodasi kepentingankepentingan dalam masyarakat, validitas undangundang yang kurang mencerminkan nilai-nilai yang hidup dalam masyarakat. Undang-undang sekarang banyak muatan kepentingan, karena dalam lembaga yang diberi wewenang untuk membuat undang-undang banyak variabel pesanan yang hendak dimasukkan dari golongon- 
golongan atau kelompok-kelompok mayoritas dan kurang memperhatikan kepentingan warga msyarakatnya.

Hakim dalam menjalankan tugasnya, terutama dalam kaitanya dengan putusan yang dijatuhkan banyak variabel yang mempengaruhi, baik yang datang dari intern hakim maupun ekstern hakim. Ada beberapa faktor yang mempengaruhi hakim dalam mengambil putusan, yaitu a. Raw in-put, yaitu faktor-faktor yang berhubungan dengan suku, agama, pendidikan informal dan sebagainya. b. instrumental in-put, yaitu faktor yang berhubungan dengan pekerjaan dan pendidikan formal. c. Environtment in-put, yaitu faktor lingkungan, sosial budaya yang mempunyai pengaruh dalam kehidupan seorang hakim, umpama lingkungan organisasi (Soerjono Soekanto, dalam Pontang Moerad BM, 2005 : 117). John Chipman Gray, mengemukakan bahwa hakim-hakim bukanlah pribadi yang bebas dari anasir-anasir non-hukum dalam menjatuhkan putusa-putusannya. Di samping unsur logika sebagai faktor utama dalam pengambilan putusan, mereka juga sangan dipengaruhi oleh subyektifitas pribadinya, prasangka dan unsur-unsur nonlogika lainnya (John Chipman Gray, dalam Adi Sulistiyono, $2002: 20$ ).

yahya Harahap, lebih memerinci faktor-faktor tersebut, faktor subyektif : 1. Sikap perilaku yang apriori, yaitu adanya sikap seorang hakim yang sejak semula sudah menganggap bahwa terdakwa yang diperiksa dan diadili adalah orang yang memang telah bersalah, sehingga harus dipidana. 2. Sikap perilaku emosional, yaitu putusan pengadilan akan dipengaruhi perangai seorang hakim. Hakim yang mempunyai perangai mudah tersinggung akan berbeda dengan perangai seorang hakim yang tidak mudah tersinggung. Hakim yang pemarah dan pendendam akan berbeda dengan hakim yang sabar. 3. Sikap arrogence power, yaitu kecongkaan kekuasaan, hakim merasa dirinya berkuasa dan pintar melebihi orang lain. 4. Moral, yaitu pribadi seorang hakim diliputi oleh tingkah laku yang didasari oleh moral pribadi hakim dalam memeriksa dan memutuskan perkara. Faktor obyektif, meliputi : 1. Latar belakang budaya. Kebudayaan, agama, pendidikan seorang hakim tentu ikut mempengaruhi suatu putusan hakim, meskipun tidak bersifat determinis. 2. Profesionalisme, yaitu kecerdasan serta profesionalisme seorang hakim ikut mempengaruhi putusan hakim (yahya Harahap, dalam Pontang Moerad BM, 2005 : 117-118)

Putusan hakim merupakan hal yang penting, di samping menyangkut kualitas dan kemampuan hakim dalam bentuk argumentasi dalam pertimbangan hukumnya juga menyangkut harkat dan martabat manusia (nasib manusia), karena putusan hakim tidak pernah mengambil jalan tengah atau draw, dan yang ada putusan kalah dan menang. Oleh karena itu, kepada para pihak disarankan sebelum mengajukan perkara atau sengketanya ke pengadilan perlu dipikir dengan lebih matang dahulu atau tidak tergesagesa memasukkan perkara ke pengadilan agar tidak mendapatkan kekecewaan dikemudian hari. Abdullah mengatakan, putusan pengadilan merupakan mahkota hakim dan inti mahkota terletak pada pertimbangan hukumnya. esensi pertimbangan hukum atau konsideran putusan merupakan bagian paling penting dalam putusan, karena merupakan pertanggungjawaban hakim terhadap putusannya. Dalam pertimbangan hukum memuat hukum penalaran dan penalaran hukum. Berbagai konstruksi dan penafsiran hukum digunakan sebagai dasar argumentasi dalam menilai dan menguji alat bukti yang diajukan dalam persidangan, antara dalil-dalil atau dasar hukum dilakukan uji verifikasi dengan fakta hukum yang terungkap di persidangan dengan menerapkan teori kebenaran dan keadilan (Abdullah, 2008 : ix).

Dalam menerapkan undang-undang, ternyata undang-undang tidak dapat mengakomodasi kebutuhan dan kepentingan warga masyarakat, seperti undang-undang tidak atau kurang jelas, undang-undang sudah usang atau ketinggalan jaman dan suatu peristiwa belum diatur dalam undang atau terjadi kekosongan undang-undang (wet vacuum) atau ada yang menyebut kekosongan hukum (recht vacuum). Sehubungan dengan hal tersebut, tugas hakim adalah memberikan kejelasan terhadap undang yang tidak atau kurang jelas lihat, agar dapat diteraplan pada peristiwanya. Sudikno Mertokusumo mengemukakan, ketentuan undang-undang tidak dapat diterapkan begitu saja secara langsung pada peristiwanya, untuk dapat menerapkan ketentuan undang-undang yang berlaku umum dan abstrak sifatnya itu pada peristiwanya yang konkret dan khusus sifatnya, ketentuan undang-undang itu harus diberi arti, dijelaskan atau ditafsirkan dan diarahkan atau disesuaikan dengan peristiwanya untuk kemudian baru diterapkan pada peristiwanya. Peristiwa hukumnya harus dicari lebih dahulu dari peristiwa konkretnya, kemudian undang-undang ditafsirkan untuk diterapkan. Setiap peraturan hukum ini bersifat abstrak dan pasif, abstrak karena umum sifatnya dan pasif karena tidak akan menimbulkan akibat hukum kalau tidak terjadi peristiwa konkret. Peraturan hukum yang abstrak itu memerlukan rangsangan agar dapat 
aktif, agar dapat diterapkan pada peristiwa yang cocok (Sudikno Mertokusumo dan A. Pitlo, 1993

: 12). Kejelasan undang-undang sangat penting, oleh karena itu setiap undang-undang selalu dilengkapi dengan penjelasan yang dimuat dalam Tambahan Lembaran Negara. Sekalipun namanya serta maksudnya sebagai penjelasan, namun seringkali terjadi bahwa penjelasan itu tidak juga memberi kejelasan, karena hanya diterangkan "cukup jelas" padahal teks undang-undangnya tidak jelas dan masih memerlukan penjelasan. Mungkin dengan demikian maksud pembentuk undang-undang hendak memberi kebebasan yang lebih besar kepada hakim (Sudikno Mertokusumo dan A. Pitlo, 1993 : 12).

Hakim dalam proses di persidangan hakim mempunyai peranan penting, bahkan dapat dikatakan sebagai aktor yang signifikan untuk menentukan kalah menangnya dalam penyelesaian sengketa atau perkara, namun kewenangan tersebut seyogyanya tidak digunakan dengan tidak benar atau cara-cara yang tidak terpuji atau hakim dengan sengaja menyalahgunakan kewenangan yang diberikan kepadanya. Hakim diharapkan dapat memberikan putusan yang seadil-adilnya sesuai dengan yang dikehendaki para pencari keadilan dalam masyarakat, karena hukum adalah untuk kepentingan manusia dan memberikan perlindungan kepadanya. Berdasarkan hal tersebut, menarik untuk dirumuskan permasalahan, yaitu bagaimanakah mengembangkan pemikiran hakim dalam menyelesaikan sengketa?

\section{B. Metode Penelitian}

Penelitian ini merupakan penelitian hukum empiris atau sosiologis, karena dalam penelitian ini ingin mengkaji lebih mendalam tentang peran hakim di muka sidang sampai dengan pengambilan putusan, dalam arti pemikiran hakim dalam menyelesaikan sengketa. Walaupun penelitian ini dengan dilakukan melalui pendekatan empiris, juga tidak meninggalkan penelitian hukum normatif, karena dalam penelitian sosiologis juga membutuhkan data sekunder sebagai data awal dalam penelitian sosiologis.

Penelitian ini bersifat deskriptif, yaitu peneliti berusaha memaparkan dan menggambarkan selengkap mungkin peran hakim di muka sidang sebagai aktor yang mempunyai peranan yang sangat penting dalam kaitannya dengan pengambilan putusan terhadap sengketa atau perkara yang diajukannya. Hakim bukan saja hanya sebagai penerap undang-undang atau membunyikan undang dalam memeriksa dan menyelesaikan sengketa, namun ia mempunyai kebebasan, mempunyai pandangan yang luas, mempunyai berbagai pertimbangan sebelum menjatuhkan putusan, sehingga putusannya sesuai dengan nilai kebenaran dan keadilan.

Data utama dalam penelitian ini adalah data primer, yaitu diperoleh melalui wawancara dengan hakim Peradlan Tata Usaha Negara yogyakarta dan Semarang. Data ini memberikan keterangan yang mendalam tertutama kaitannya dengan obyek penelitian, berupa pemikiranpemikiran hakim dalam menyelesaikan sengketa yang dituangkan dalam putusan hakim melalui pertimbangan hukumnya. Data primer diperoleh melalui wawancara secara mendalam (indepth interview), dalam bentuk wawancara tak berstruktur dengan memberikan pertanyaan-pertanyaan yang sebelumnya telah dipersiapkan dan disusun lebih dahulu oleh interviewer. Data sekunder diperoleh melalui bahan pustaka atau studi kepustakaan, hal ini dimaksudkan untuk menelusuri tentang berbagai masalah yang berkaitan dengan perundang-undangan PTUN, buku, hasil penelitian dan putusan pengadilan (PTUN).

Sesuai dengan data yang dikumpulkan dan juga dengan jenis penelitian yang dilakukan, maka teknik analisisnya adalah dengan deskriptif kualitatif. Berkaitan dengan hal tersebut, Soerjono Soekanto mengemukakan bahwa pendekatan kualitatif sebenarnya merupakan tata cara penelitian yang menghasilkan data deskriptif, yaitu apa yang dinyatakan oleh responden secara tertulis atau lisan, dan juga perilakunya yang nyata, diteliti dan dipelajari sebagai sesuatu yang utuh. Dengan kata lain, seorang peneliti yang mempergunakan metode kualitatif, tidaklah semata-mata bertujuan untuk mengungkapkan kebenaran belaka, tetapi juga memahami kebenaran tersebut (Soerjono Soekanto, 1986, 250). Dikemukakan selanjutnya untuk mengetahui latar belakang itu semua, perlu dijelaskan dengan tiga macam pengertian, yaitu fenomenologi, interaksi simbolik dan etnometodologi. Dalam penelitian doktrinal, maka analisis data dilakukan dengan menggunakan analisis normatif kualitatif. Peneliti melakukan inventarisasi hukum dan berbagai norma hukum, aturan-aturan hukum, hasil penelitian, putusan pengadilan (PTUN), dengan menggunakan logika deduktif.

\section{Hasil Penelitian dan Pembahasan}

\section{Tugas Hakim Menyelesaikan Sengketa}

Produk pengadilan dibedakan menjadi dua, yaitu putusan (vonnis) dan penetapan (beschikking). Ada beberapa unsur yang membedakan antara putusan dan penetapan. 
Putusan (vonnis), adanya dua pihak yang bersengketa, misalnya dalam pengadilan tata usaha negara, yaitu antara seseorang atau badan hukum perdata dengan Badan atau Pejabat tata usaha negara atau pemerintah. Sifat peradilan adalah jurisdictio contentiosa atau peradilan yang sesungguhnya dan produk pengadilan berupa putusan (vonnis). Dalam penetapan (beschikking) tidak ada unsur sengketa, karena hanya ada satu pihak, yaitu sebagai pemohon (kecuali dalam perkawinan) yang mengajukan permohonan kepada hakim untuk mendapatkan kejelasan, sehingga produk pengadilan berupa penetapan (beschikking). Sifat peradilan adalah volunter (peradilan yang tidak sesungguhnya), atau eksecutive power dan putusan hanya mengikat pemohon saja (Roihan A. Rasyid, 2002 : 56-57).

Putusan merupakan akhir suatu proses pemeriksaan perkara yang dilakukan majelis hakim dengan terlebih dahulu dilakukan musyawarah berdasarkan ketentuan peraturan perundang-undangan. Putusan merupakan pernyataan hakim sebagai pejabat negara yang diberi wewenang, diucapkan di persidangan dan bertujuan untuk menyelesaikan suatu perkara antara para pihak (Soedikno Mertokusumo, 1998 : 167). Hakim harus mengadili, menyelesaikan perkara yang diajukan kepadanya dan harus memberi putusan, karena hakim/pengadilan dilarang menolak untuk memeriksa, mengadili dan memutus suatu perkara yang diajukan dengan dalih bahwa hukum tidak ada atau kurang jelas, melainkan wajib untuk memeriksa dan mengadilinya (Pasal 10 UU Nomor 48 Tahun 2009). Pasal 5 ayat (1) Undang-undang Nomor 48 Tahun 2009, menyebutkan hakim dan hakim konstitusi wajib menggali, mengikuti dan memahami nilai-nilai hukum dan rasa keadilan yang hidup dalam masyarakat.

Tujuh langkah yang harus dilakukan oleh hakim dalam kaitannya dengan penerapan hukum untuk menyelesaikan sengketa atau peristiwa, yaitu :

1. Meletakan kasus dalam sebuah peta (memetakan kasus) atau memaparkan kasus dalam sebuah ikhtiar (peta), artinya memaparkan secara singkat duduk perkaranya dari sebuh kasus (menskematisasi).

2. Menerjemahkan kasus itu ke dalam peristilah yuridis (mengkualifikasi, pengkualifikasian)
3. Menyeleksi aturan-aturan yang relevan.

4. Menganalisis dan menafsirkan (interpretasi) terhadap aturan-aturan hukum.

5. Menerapkan aturan-aturan hukum pada kasus

6. Mengevaluasi dan menimbang (mengkaji) argumen-argumen dan penyelesian

7. Merumuskan formulasi penyelesaian $(\mathrm{Gr}$. Van der Brught dan J.D.C. Winkelman, dalam Sidharta, $2004: 177)$.

Roccoe Pound, mengemukakan ada tiga langkah yang dilakukan hakim hakim dalam mengadili suatu perkara, yaitu :

1. Menemukan hukum, menetapkan kaidah mana dari sekian banyak kaidah di dalam sistem hukum yang akan diterapkan, atau jika tidak ada yang dapat diterapkan (yang mungkin atau tidak mungkin) dipakai sebagai satu kaidah untuk perkara lain sesudahnya berdasarkan bahan yang sudah ada menurut suatu cara yang ditunjukkan oleh sistem hukum.

2. Menafsirkan kaidah yang dipilih atau ditetapkan secara demikian, yaitu menentukan maknanya sebagaimana pada saat kaidah itu dibentuk dan berkenaan dengan keluasaannya yang dimaksud

3. Menerapkan pada perkaranya yang sedang dihadapi kaidah yang ditemukan dan ditafsirkan demikian (Roscoe Pound, diterjemahkan Moh. Radjab, 1972 : 62).

Sudikno Mertokusomo mengemukakan, hakim haruslah mengkonstatir benar tidaknya peristiwa yang diajukan. Mengkonstatir berarti melihat, mengakui atau membenarkan telah terjadinya suatu peristiwa yang diajukan tersebut dan untuk sampai pada konstatering, hakim harus mempunyai kepastian. Hakim harus pasti akan konstateringnya itu, ia harus pasti akan kebenaran peristiwa yang dikonstatirnya, sehingga konstateringnya itu tidak sekedar dugaan atau kesimpulan yang dangkal atau gegabah tentang adanya peristiwa yang bersangkutan. Dalam hal tersebut, hakim harus menggunakan saranasarana atau alat-alat untuk memastikan dirinya tentang kebenaran peristiwa yang, maka bersangkutan. Hakim harus melakukan pembuktian dengan alat-alat tersebut untuk mendapatkan kepastian tentang peristiwa yang diajukan kepadanya. Tahap kedua, hakim mengkualifisir peristiwanya. Mengkualifisir 
berarti menilai peristiwa yang telah dianggap benar-benar terjadi itu termasuk hubungan apa yang mana atau menemukan hukumnya bagi peristiwa yang telah dikonstatir. Untuk menemukan hukumnya hakim sering melakukan penerapan hukum terhadap peristiwanya. Dicarikan dari peraturan hukum yang ada, ketentuan-ketentuan yang dapat diterapkan pada peristiwa yang bersangkutan. Kalau peristiwanya sudah terbukti dan peraturan hukumnya jelas dan tegas, maka penerapan hukumnya pada umumnya merupakan pekerjaan yang boleh dikatakan mudah. Mengkualifisir pada umumnya berarti menemukan hukumnya dengan jalan menerapkan peraturan hukum terhadap peristiwa, suatu kegiatan yang pada umumnya bersifat logis. Dalam kenyataannya menemukan hukum tidak sekedar menerapkan peraturan hukum terhadap peristiwanya saja. Lebih-lebih kalau peraturan hukumnya tidak tegas dan tidak jelas, maka dalam hal ini hakim tidak lagi harus menemukan hukumnya, melainkan menciptakan sendiri. Dalam kaitan dengan hal tersebut menurut Cardozo, seorang hakim terkenal dari Amerika menyebutkan :"the law which is the resulting product is not found but made. The process in its bighest reaches is not discovery, but creation". Mengkualifisir peristiwa mengandung unsur kreatif, sehingga daya cipta hakim besar sekali peranannya. la harus berani menciptakan hukum yang tidak bertentangan dengan keseluruhan sistem perundang-undangan dan memenuhi pandangan masyarakat serta kebutuhan jaman. Tahap ketiga, hakim harus mengkonstitur. Hal ini berarti hakim menetapkan hukumnya terhadap peristiwa yang bersangkutan, memberi keadilan. Hakim mengambil kesimpulan dari adanya premise mayor, yaitu (peraturan) hukum dan premise minor, yaitu peristiwanya. sekalipun ini merupakan silogisme, tetapi bukan semata-mata hanya logika saja yang menjadi dasar kesimpulannya. Keadilan yang diputuskan oleh hakim bukanlah produk dari intelek hakim, "but of his spirit", kata Sir Alferd Denning, seorang hakim terkenal di Inggris (Adi Sulistiyono, 2006 : 75-76). Diperlukan hakim yang mau dan mampu berpikir dalam menyelesaikan sengketa, sebagaimana dikemukakan Achmad Ali dengan mengambil pendapat Carbonnier :"les choses out toujours du se passer ainsi, des millenaires gu'ily a dsejuges, et gui passent" (demikianlah senantiasa telah terjadi bahwa selama ribuan tahun, dituntut adanya para hakim yang berpikir).

Tugas utama hakim adalah menghubungkan aturan abstrak dalam undang-undang dengan fakta konkret dari perkara yang diperiksanya. Dalam hubungan ini, apakah hakim seperti yang diisyaratkan oleh trias politikanya Montesquie hanya menerapkan undang-undang atau hakim harus menggunakan pikirannya atau penalaran logisnya untuk membuat interpretasi terhadap aturan yang ada dalam perundang-undangan. Selama berabad-abad, hubungan antara perundang-undangan dengan putusan hakim menimbulkan polemik yang tak putusputusnya dan melahirkan berbagai aliran pemikiran dalam ilmu hukum. Mula-mula dikenal aliran legisme, yang cenderung memandang hakim hanya sekedar terompet undang-undang (bouche de la loi). Kemudian muncul aliran penemuan hukum oleh hakim yang memandang hakim dapat mengisi kekosongan perundang-undangan dengan jalan konstruksi hukum atau interpretasi hukum. Terakhir, muncul lagi aliran realis di Amerika Serikat dan Skandinavia yang pada pokoknya memandang hakim tidak sekedar "menemukan hukum" melainkan "membentuk hukum" melalui putusannya. Bagi aliran realisme, kaidah-kaidah hukum yang berlaku memang ada pengaruhnya terhadap putusan hakim, tetapi hanya sebagai salah satu unsur pertimbangan. Selain unsur kaidah hukum itu, putusan hakim juga dipengaruhi oleh prasangka politik, ekonomi ataupun moral, bahkan perasaan simpati dan antipati pribadi turut mempengaruhi putusan hakim (Achmad Ali, 2008 : 104).

Pandangan legime yang mempengaruhi aliran positivisme hukum, memandang bahwa undang-undang merupakan satu-satunya sumber hukum dan undang-undang hanyalah dalam bentuknya yang tertulis, di luar tersebut bukan merupakan undang-undang. Amin mengemukakan, aliran legitimisme sangat mengagungkan hukum tertulis, sehingga aliran ini beranggapan bahwa tidak ada norma hukum di luar hukum positif, semua persoalan dalam masyarakat diatur dalam hukum tertulis. Pandangan yang sangat mengagungagungkan hukum tertulis pada positivisme hukum ini, pada hakikatnya merupakan penghargaan yang berlebihan terhadap kekuasaan yang menciptakan hukum tertulis itu, sehingga dianggap kekuasaan itu adalah sumber hukum dan kekuasaan adalah hukum 
(Amin, 1952, dalam Riduan Syahrani, 2003 : 44). Pada abad 19 munculah pandangan legisme atau legalitas yang menganggap bahwa hukum adalah undang-undang. Undang-undang dianggap keramat, sebagai peraturan yang dikukuhkan Allah sendiri atau sebagai sistem yang logis yang berlaku bagi semua perkara karena bersifat rasional yang disebut teori rasionalitas atau teori indeenjurisprudenz (L. Pospisil, dalam Prasetyo Hadi Purwandoko, 1996 : 40).

Hakim dalam tugasnya tidak selalu terikat pada ketentuan-ketentuan dalam undangundang, hakim mempunyai pandangan yang lebih luas dan kebebasan dalam menerapkan undang-undang. Mead mengemukakan manusia mempunyai kepribadian sendiri dan karena ia mempunyai kemampuan untuk menciptakan sasaran tindakantindakannya sendiri. Manusia mempunyai sejumlah kemungkinan tindakan dalam pemikiran sebelum ia memulai tindakan yang sebenarnya. Sebelum melakukan tindakan yang sebenarnya, seseorang mencobakan terlebih dahulu berbagai alternatif tindakan itu secara mental melalui pertimbangan pemikirannya. Selanjutnya dikemukakan berpikir menurut Mead, adalah suatu proses di mana individu berinteraksi dengan dirinya sendiri dengan mempergunakan simbolsimbol yang bermakna. Melalui proses interaksi dengan diri sendiri itu, individu memilih yang mana di antara stimulus yang tertuju kepadanya itu yang akan ditanggapinya. Individu tidak secara langsung menanggapi stimulus, tetapi terlebih dahulu memilih dan kemudian memutuskan stimulus mana yang akan ditanggapi. Sesudah stimulus dipilih, individu mencobakan berbagai tanggapan dalam pikiran sebelum tanggapan yang sesungguhnya diberikan. Aktor memilih ke depan dan memastikan akibat atau hasil dari berbagai tindakan yang akan dipilihnya itu (George Ritzer, dalam Alimandan : 67).

Sehubungan dengan tersebut menarik untuk dikemukakan pandangan Glendon Schubert, hakim itu setuju atau tidak setuju terhadap suatu putusan, bukan karena mereka melakukan penalaran yang sama atau berlainan, melainkan karena mereka mempunyai sikap-sikap yang sama atau berlainan. Para hakim berbeda-beda dalam sikap-sikapnya oleh karena masing-masing pada akhirnya memiliki beberapa untuk dipercayainya dan menolak yang lain sebagai hasil dari pengalaman hidupnya.
Apa yang dipercaya oleh seorang hakim tergantung dari afiliasi-afiliasi politik, agama, dan etnisnya, baik formal maupun bukan, kariernya di bidang hukum sebelum menjadi hakim. Afilias-afiliasi yang berhubungan dengan perkawinan, status sosial ekonomi, pendidikan dan kariernya, pada gilirannya untuk bagian terbesar dipengaruhi oleh tempat ia dilahirkan dari orang tua siapa dan kapan. Dalam menerima pengaruh atau rangsangan dari luar, baik dari lingkungan sosial maupun budaya, hakim tidak akan bertindak sebagai robot, dalam arti tindakan yang diambil semata-mata sebagai tindakan atas rangsangan atau stimulus sosial, tetapi tindakan tersebut dilakukan sebagai hasil dari proses interpretasi atau penafsiran terhadap stimulus sosial tersebut (Glendon Schubert, dalam Antonius Sudirman :34). Pandangan tersebut dikuatkan Blumer, bahwa tindakan manusia terdiri dari pertimbangan atas berbagai hal yang diketahuinya dan melahirkan serangkaian kelalkuan atas dasar bagaimana ia menafsirkan hal tersebut. Hal yang dipertimbangkan mancakup, keinginan dan kemauan, tujuan dan sarana yang tersedia untuk mencapainya serta tindakan yang diharapkan dari orang lain (Blumer, dalam Margaret M Poloma, 1994 : 268).

Pemikiran hakim dalam proses di pengadilan dalam rangka menyelesaikan perkara atau sengketa sudah seharusnya bergeser atau merubah dari cara-cara yang lama (mendasarkan pada undang-undang sebagai produk atau hasil legislatif) ke pemikiran yang banyak memperhatikan kepentingan atau kebutuhan dalam masyarakat. Hakim sebagai penegak hukum dan keadilan harus mampu mengakomodasi eksistensi perkembangan hukum di dalam masyarakat. Hukum tidak hanya dimaknai sebagai tertulis dalam undang-undang, tetapi juga yang hidup di dalam masyarakat atau living law, kearifan lokal tidak boleh lepas dari pengamatan hakim dalam memutus perkara atau sengketa. Danah Zohar dan lan Marshall mengemukakan, cara berpkir manusia yang paling sederhana memang mirif dengan mesin, yang biasa disimbolkan dalam lq (intellectual quotient). Untuk waktu yang lama cara berpikir seperti itu mewakili kemampuan berpikir manusia, sehingga semua ingin diukur dengan standar lq. Model berpikir tersebut sebagai serial thinking, juga disebut simplistic model of thinking, yaitu berpikir secara lurus, logis dan tanpa 
melibatkan emosi. Hal tersebut tidak salah, tetapi lq saja belum menggambarkan atau mewakili cara berpikir manusia seluruhnya. Untuk melengkapi Iq, kemudian muncul eq (Emotional Quotient), yaitu berpikir asosiatif atau berpikir dengan hati dan badan. Terakhir adalah Sq (spiritual quotient), yang oleh Danah Zohar dan Marshall dinobatkan sebagai intelegensi yang paling sempurna. Berbeda dengan Iq, maka Sq disebut unitive thinking yang melahirkan kecerdasan spiritual, yaitu kecerdasan yang bermakna (meaning-giving), berpikir dalam konteks dan melompat keluar dari ikatan (transformative). Pensifatan lain untuk Sq adalah berpikir kreatif, penuh wawasan (insightful) dan intuitif (Danah Zohar dan lan Marshall, dalam Satjipto Rahardjo, 2007 : 93).

Cara berhukum yang legalistik, positif analitis disebut sebagai rule making, pemikiran kreatif dan intuitif disebut rule breaking (Satjipto Rahardjo, 2007 : 94). Selanjutnya dikemukakan bahwa diserahkan kepada manusia, berarti membiarkan hukum untuk bisa membuat putusan-putusan yang penuh dengan pilihan-pilihan. Dalam keadaan sekarang, manusialah yang mampu menyelesaikan pekerjaan yang penih dengan pilihan tersebut. Hal ini didukung oleh pendapat Danah Zohar dan Marshall, bahwa manusia memiliki kemampuan berpikir yang tidak hanya logis, masinal dan serial, melainkan kreatif dan rule breaking. Hukum tidak pernah bisa melayani manusia, apabila ia tidak juga bekerja dengan penuh perasaan dan kepedulian (compassionate). Untuk dapat melayani manusia dengan baik, maka hukum tidak bisa hanya menghitung dan mengeja pasal-pasal undang-undang, melainkan juga bekerja dengan modal empati dan keberanian (dare) dan itu belum mampu dilakukan mesin. Hakim yang berani melakukan terobosan dan berupaya mendapatkan keadilan substantif atau keadian dalam masyarakat.

Daniel S Lev menggunakan istilah keadilan prosedural dan substantif, sedangkan Schuyt menggunakan istilah keadilan formal dan material. Keadilan formal atau prosedural komponennya berhubungan dengan gaya suatu sistem hukum, seperti rule of law atau negara hukum rechtstaat. Adapun komponen keadilan substantif atau material menyangkut apa yang dewasa ini dinamakan hak-hak sosial serta menandai politik, ekonomi dalam masyarakat. Konsepsi keadilan berakar dari kondisi masyarakat yang diinginkan. Konsep keadilan yang pada hakikatnya masih berupa gagasan-gagasan yang abstrak yang lebih sulit untuk dipahami, akan lebih mudah memahami adanya ketidakadilan dalam masyarakat (Mulyana W. Kusumah, 1981 : 53). Dicontohkan hakim yang jujur, mempunyai keberanian untuk memutus berdasarkan hati-nurani, empati dan perasaan, dan produk dikeluarkan berupa keadilan substansial, Bismar Siregar, Adi Andojo Satjipto, Benyamin Mangkudilaga, Asikin Kusuma Atmadja. Di tengah-tengah muramnya dunia kekuasaan kehakiman di Indonesia, beliau muncul menyinari kegelapan dunia hukum (http//www, hamline. edu/apakabar/basisdata/1996).

\section{Mengembangkan Pemikiran Hakim.}

Keadilan sebagaimana diharapkan warga masyarakat tidak mudah untuk diwujudkan sebagai produk pengadilan. Di satu pihak apabila hakim mengedepankan kepastian hukum, dia akan meninggalkan atau mengesampingkan keadilan dan sebaliknya. Dominasi aliran legisme dan positivisme hukum dalam proses peradilan tidak dapat dihindari, pemikiran hakim terbelenggu oleh kekuatan undang-undang yang lebih mengedepankan keadilan formal atau prosedural. Hakim tidak melakukan penafsiran terhadap undang-undang, hakim bersikap pasib, sehingga hakim hanya terkesan membunyikan ketentuanketentuan dalam undang-undang. Pengaruh yang demikian kuatnya dalam masyarakat maupun dalam proses peradilan, hakim tidak dibenarkan dan tidak diperbolehkan melampaui batas-batas ketentuan undangundang. Anthon F. Susanto mengemukakan, penafsiran hukum oleh hakim tidak boleh melampaui batas-batas yang dibuat oleh legislatif (Belanda : binnen het kader van de wet) dalam kaitan tersebut muncul aliran seperti begriffsjurisprudenz bersama yang lain seperti dogmatik hukum, normatif hukum legal ositivism, yang menganggap teks hukum sebagai sesuatu yang memiliki otonomi mutlak (Anthon F. Susanto, $2005: 7$ )

Hal yang demikian tidak boleh dibiarkan terus berlangsung, karena masyarakat yang mendambakan keadilan akan menjadi terbengkelai atau menjadi dilupakan oleh peran hukum. Satjipto Rahardjo mengemukakan, hukum akan menjadi statis dan stagnan manakala tidak ada usaha menyiangi dan menyingkirkan hambatan-hambatan yang 
menyebabkan hukum menjadi stagnan. Salah satu hal yang akan terhambat adalah tidak munculnya kekuatan yang sebenarnya ada secara inheren dalam hukum. Kekuatan yang tersimpan itu menjadi tidak muncul karena para penegak hukum sendiri yang menyebabkannya. Penghambatnya adalah cara berhukum yang hanya mengeja teks undang-undang (Satjipto Rahardjo dalam Siti Malikhatun Badriyah, 2010 : 63).

Trio filsof Athena (Socrates, Plato, Aristoteles) menekankan aspek keadilan. Hakikat hukum adalah keadilan. Hukum berfungsi melayani kebutuhan keadilan dalam masyarakat, hukum menunjuk pada suatu aturan hidup yang sesuai dengan cita-cita tentang hidup bersama, yaitu keadilan. Isi kaidah hukum harusnya adil, tanpa keadilan, hukum hanya merupakan kekerasan yang diformalkan. Hukum dirasakan penting ketika kita dihadapkan pada ketidakadilan. Orang menuntut ke pengadilan, sebenarnya untuk meminta keadilan. Jadi sebenarnya pengadilan untuk keadilan. Oleh karena itu, ius sebenarnya tidak sama dengan lege atau lex. Lege menunjuk pada suatu aturanaturan hukum yang faktual ditetapkan, tanpa mempersoalkan mutunya. Ius menunjuk pada cita hukum yang harus tercermin dalam hukum sebagai hukum, yaitu keadilan. Ius tidak selalu bisa ditemukan dalam segala aturan hukum (lege/lex). Das volk des recht ist nicht das volk des gesetzes (bangsa hukum, bukan bangsa undang-undang), demikian salah satu adagium Romawi (Bernard L. Tanya, yoan N. Simanjuntak, Markus y. Hage, 2010 : 219-220). Selanjutnya dikemukakan bahwa selepas abad ke-19, hukum kembali dikaitkan lagi dengan mosaik sosial dan kemanusiaan. Melalui Radbrucht, hukum kembali dikaitkan dengan keadilan. Melalui Marx, Holmes, Rawls dan lainnya, hukum dikaitkan dengan upaya mewujudkan keadilan sosial. Hukum merupakan bagian dari perjuangan mewujudkan keadilan sosial. Oleh karena itu, muncul kehendak meninggalkan tradisi analytical jurisprudence atau rechtsdogmatiek yang hanya melihat ke dalam hukum dan menyibukkan diri dengan membicarakan dan melakukan analisis ke dalam, khususnya hukum sebagai suatu bangunan peraturan yang dinilai sebagai sistematis dan logis.

Keadilan merupakan salah satu tujuan dari setiap sistem hukum dan menurut Plato, keadilan merupakan nilai kebajikan yang paling tinggi (justice is the supreme virtue which harmonize all other virtues) (Munir Fuady, 2003 : 52). Orang yang adil adalah the self dicliplined man whose pasions are controlled by reason atau orang yang mengendalikan diri yang perasaan hatinya dikendalikan oleh akal. Menurut Aristoteles, keadilan yaitu kelayakan dalam tindakan manusia atau fairness in human action. Aristoteles membagi keadilan menjadi keadilan komutatif dan keadilan distributif. Menurut Thomas Hobbes, tidak ada keadilan alamiah yang lebih tinggi daripada hukum positif. Immanuel Kant mengemukakan, keadilan merupakan kebebasan ekstrim dari setiap orang yang dibatasi oleh kebebasan dari semua orang lainnya. Keadilan merupakan sintesa dari kebebasan dan persamaan (Abdullah, 2008 : xi).

Gustav Radbruch mengemukakan, dalam perkembangannya hukum mencari idealnya, yaitu terwujudnya tiga ide dasar dalam berhukum. yaitu kepastian hukum (rechtssicherheid), keadilan (gerechtigkeit) dan kemanfaatan (zweckmassigkeit). Peribahasa latin yang cukup terkenal mengenai urgensi keadilan menyebutkan : fiat justisia et pereat mundus (ruat coelum), artinya hukum yang keadilan harus dilaksanakan sekalipun dunia harus kiamat atau sekalipun langit runtuh karenanya (Abdul Ghofur Anshori dan Sobirin Malian, 2008 : 87). Peribahasa tersebut menyiratkan suatu komitmen yang sangat tinggi untuk mewujdkan keadilan di dalam kehidupan bersama. Satjipto Rahardjo mengemukakan, hukum dan keadilan adalah dua hal yang berjalan beriringan dan tidak dapat dipisahkan. Hukum dibuat dan ditetapkan adalah agar orang yang berada di bawah naungan hukum tersebut menikmati dan merasakan keadilan. Hukum adalah untuk manusia dan bukan sebaliknya (Satjipto Rahardjo, 2007 : 47). Keadilan merupakan salah satu tujuan dari hukum. Upaya untuk mewujudkan keadilan dalam hukum tersebut merupakan proses yang dinamis dan membutuhkan waktu yang tidak singkat. Upaya ini seringkali didominasi oleh kekuatan-kekuatan yang bertarung dalam kerangka umum tatanan politik untuk mengaktualisasikannya (Carl Joachim Friendrich, 2004 : 239).

Perkembangan pemikiran keadilan terus berlanjut sesuai dengan perkembangan pemikiran tentang hukum disepanjang masa. Misalnya, kaum hedonisme (Jeremy 
Bentham) percaya bahwa keadilan baru ada jika membawa manfaat/kesenangan yang sebesar-besarnya bagi sebanyak mungkin manusia. Kaum positivisme (John Austin) meyakini bahwa keadilan adalah apa yang diputuskan oleh penguasa. Hans Kelsen, baru adil jika diterapkan sesuai dengan konstitusi. Pada abad ke 20 sudah mulai ditinggalkan pemberian arti kepada keadilan sebagai perlindungan kebebasan individu (individual liberty), dengan lebih memberikan tempat kepada masyarakat (Munir Fuady, 2007 : 89).

Satjipto Rahardjo mengemukakan, praksis hukum selama ini mengikuti cara "menegakkan hukum menurut bunyi teks" (black-letter law) yang hanya menurut katakata dan kalimat dalam teks. Demikian, praksis abad ke-19 masih menguasai pemikiran dan praksis hukum sampai hari ini. Sekarang cara berhukum diproyeksikan terhadap gagasan atau pemahaman yang baru, yaitu menukik sampai pada kedalaman makna hukum :

a. Para penegak hukum dimanapun posisi mereka, mengidentifikasi diri mereka sebagai kaum vigilantes, orang-orang yang berjihad dalam hukum. Mereka tidak hanya membaca undang-undang, tetapi diresapi dengan semangat untuk meluapkan keluar makna undangundang yang ingin menyejahterakan rakyat. Mereka bukanlah tipe orangorang yang "mengangkat pundaknya" seraya mengatakan : apa boleh buat, hukumnya memang begitu. Diperlukan predisposisi progresif dari para penegak hukum.

b. Kesadaran dan keyakinan bahwa hukum menginginkan yang baik terjadi pada rakyat dan masyarakat. Hukum bukan semata-mata berupa sederetan katakata dan kalimat. Hukum adalah pesan (message) yang membutuhkan realisasi. Hukum sebagai 'kalimat' dan 'pesan' adalah dua hal yang sangat berbeda dan yang pada akhirnya akan menentukan hasil putusan (Satjipto Rahardjo, 2009 : 54).

Sebagaimana dikemukakan Satjipto Rahardjo bahwa hukum untuk manusia adalah merupakan pemikiran filosofi, hukum bukan untuk dirinya sendiri, melainkan untuk yang lebih luas, yaitu untuk harga diri manusia, kebahagiaan, kesejahteraan dan kemuliaan manusia. Dengan filosofi tersebut, maka manusia menjadi penentu dan titik orientasi hukum (Satjipto Rahardjo,
2008 : 188). Dengan demikian hakim sebagai aktor yang sangat dominan dalam proses peradilan mempunyai tugas dan peran yang semakin berat, mereka tidak boleh hanya mengandalkan eksistensi peraturan perundang-undangan yang berlaku sebagai dasar untuk menjatuhkan putusan, melainkan harus peka dan kreatif dalam menyelsaikan perkara yang dihadapinya. Bernard L. Tanya dkk mengemukakan, para pelaku hukum progresif dapat melakukan perubahan dengan melakukan pemaknaan yang kreatif terhadap peraturan yang ada, tanpa harus menunggu perubahan peraturan (changing of law). Peraturan buruk tidak harus menjadi penghalang bagi para pelaku hukum progresif untuk menghadirkan keadilan rakyat dan pencari keadilan, karena mereka dapat melakukan interpretasi secara baru setiap kali terhadap suatu peraturan (Bernard L. Tanya, yoan N. Simanjuntak, Markus y. Hage, 2010 : 212-213).

Undang-undang Nomor 48 Tahun 2009 Pasal 5 ayat (1) menyebutkan bahwa hakim dan hakim konstitusi wajib menggali, mengikuti dan memahami nilai-nilai hukum dan rasa keadilan yang hidup dalam masyarakat. Aliran realisme mengajarkan bahwa hukum yang baik dan dapat berlaku secara effektif adalah hukum yang sesuai dengan nilai-nilai yang hidup dalam masyarakat dan begitu pentingnya keberadaan nilai-nilai hukum yang hidup dalam masyarakat. Brian Z. Tamanaha sebagai ahli hukum dari Jepang sangat menaruh perhatian terhadap eksistensi hukum yang hidup dalam masyarakat. Tamanaha mengemukakan, hukum itu merupakan pencerminan dari nilai-nilai yang berlaku dalam masyarakat. Hukum yang baik adalah hukum yang sesuai dengan hukum yang hidup ( the living law) dalam masyarakat (Brian Z. Tamanaha, 2006 : 1-2).

Hakim tidak saja dituntut untuk memahami hukum yang telah dipositifkan, tetapi lebih dari sekedar itu hakim harus pula memahami makna yang terkandung dibalik hukum yang telah dipositifkan (asas, nilai-nilai). Seorang hakim harus sadar akan ideologi dan subyektifitasnya sendiri, sehingga keduanya tidak akan mengintervensi proses interpretasi. Untuk mengungkap makna teks sebuah aturan tertentu, hakim harus mulai dengan pembacaan awal, kemudian dilanjutkan dengan pembacaan analisitis, agar kunci dan gagasan-gagasan sentral teks dapat dibuka. Melakui gagasan-gagasan 
sentral tersebut, hakim diharapkan dapat menemukan makna yang tersembunyi dan mengembangkan makna-makna baru. Penjelasan tersebut mengarahkan kepada usaha yang harus dilakukan seorang hakim, yaitu membaca secara kontekstual, artinya hakim harus memiliki kreativitas untuk membaca realita faktual dan realita simbolik. Harus diakui bahwa proses interpretasi juga sebagai sebuah proses dekoding yang tiada henti, dimana penafsir harus mempertimbangkan atau memperhatikan makna sosio-kultural kontekstual, dengan menggunakan kritik historis. Seorang hakim harus memperhatikan bahwa level makna yang dapat dicapai memiliki tingkatantingkatan tertentu, ada level permukaan, metavor dan hakiki, dan untuk mengungkap ketiga makna tersebut hakim harus mencoba untuk berpikir transenden, kritis dan progresif. Transenden berarti optimalisasi nurani dalam melakukan penafsiran. Kritis adalah penggunaan nalar, namun tidak bersifat 'take for granted'. Progresif adalah upaya untuk terus menemukan makna-makna baru dan tidak terbelenggu oleh makna absolut (Anthon F Susanto, 2005 : 152).

Hakim sebagai penegak hukum dan keadilan dituntut untuk melakukan langkahlangkah terobosan dalam menyelesaikan sengketa atau perkara di pengadilan, kreatif, arif dan visioner, tidak sekedar menerapkan peraturan perundang-undangan secara kaku. Satjipto Rahardjo mengemukakan, di abad ke-19, yaitu pada era hukum mekanistik berlangsung, hakim hanyalah mulut undangundang (la bouche qui prononcent les paroles de la loi). Bangunan hukum kelsenian sama dengan pikiran Newtonian yang melihat alam sebagai bangunan besar yang disusun dari blok ke blok secara mekanistik. Orang sekarang sudah melihat masyarakat sebagai sesuatu yang kompleks, relatif dan tidak dapat dipahami secara matematis. Sehubungan dengan hal tersebut, Oliver Wendell Holmes mengemukakan, the law embodies the story of a nation's delelopment through many centuries, and it can not be dealt with as if it contained only the axioms and corollaries of a book of mathematics. Rupanya ilmu sekarang tidak puas hanya menjadi 'ilmu hukum' (jurisprudence), melainkan lebih daripada itu. Keinginan tersebut, misalnya tercermin pada buku Brian Z. Tamanaha, berjudul $A$ general jurisprudence of law and society. IImu hukum tidak berhenti pada studi mengenai teks dan dokumen, melainkan hukum dalam konteks masyarakat. Perkembangan ilmu hukum sudah menjawab tantangan garis depan sains yang pahamnya sudah bergeser 'mekanistik ke holistik'. IImu hukum mengalami pergeseran dari konteks ke sosial (satjipto Rahardjo, 2009 : 126).

Tuntutan masyarakat pada hakim sangat beralasan, di samping perkembangan masyarakat yang semakin kompleks, kemajuan ilmu dan teknologi, komunikasi, juga berbagai pendapat ahli yang mengajak para penegak hukum untuk memperhatikan realita di dalam masyarakat. Fritjoff Capra mengemukakan, adanya pemahaman yang menyeluruh terhadap berbagai aspek kehidupan dan Indonesia yang memiliki struktur masyarakat yang pulral, dapat dilakukan dengan pendekatan yang dikemukakan Capra melalui teori kompleksitasnya (complexity theory). Dengan bukunya the web of life, ia mengemukakan perkembangan pemikiran yang semula berkotak-kotak (fragmented) ke arah pemikiran yang menyeluruh atau holistik (from logos to holos) (Fritjoff Capra, dalam Siti Malikhatun Badriyah, 2010 : 30). Mengingat adanya kompleksitas yang ada di dalam masyarakat, maka hukum harus dilihat dengan pendekatan baru sebagaimana dikemukakan oleh Werner Menski yang disebut sebagai triangular concept of legal pluralism (Werner Menski, 2006, dalam Siti Malikhatun Badriyah, 2010 : 30). Konsep pluralisme dari Werner Menski tersebut dihubungkan dengan konsep Lawrence $\mathrm{M}$. Friedman tentang tiga unsur sistem hukum, yaitu substansi, struktur dan kultur hukum dan hal tersebut menjadi tugas hakim sebagai penegak hukum dan keadilan dalam perannya untuk mewujudkan keadilan sosial atau plural, keadilan substantif atau material yang selalu diharapkan dan diidamkan warga masyarakat.

Legal pluralism sebagaimana dikemukakan Werner Menski merupakan strategi baru yang harus dikuasai oleh penegak hukum termasuk hakim agar dapat benar-benar memberikan keadilan bagi parapencari keadilan (justisiabellen) atau masyarakat pada umumnya dengan melakukan suatu lompatan dengan cara berhukum yang tidak hanya terkungkung pada legalitas formal (legal formalism), tetapi juga dengan pertimbangan living law dan natural law (Siti Malikhatun Badriyah, 2010 : 32). Dengan demikian diharapkan ada perubahan 
pemikiran hakim atau pergerakan untuk menggeser pemikiran hakim dalam proses di pengadilan. Satjipto Rahardjo menawarkan apakah pengadilan membutuhkan suatu rekonstruksi besar-besaran, hal tersebut sangat mungkin memang itu yang dibutuhkan. Barangkali bukan hanya rekonstruksi, tetapi sebelumnya itu rupa-rupanya perlu melakukan dekonstruksi terhadap pengadilan terlebih dahulu. Dekonstruksi dalam hal ini adalah membuang cara kerja pengadilan yang lama. Dekonstruksi sebaiknya bermula dari sikap para hakim terhadap pekerjaannya dan cara berpikir mereka. Beliau lebih condong pada perubahan perilaku dan pemikiran hakim daripada merubah hukum (Satjipto Rahardjo, dalam Anthon F. Susanto, 2004 : 15). Pergeseran pemikiran hakim dari positivistik menuju ke arah pemikiran yang holistik dan ekologis, diharapkan dapat dan mampu mewujudkan keadilan substantif sebagaimana dicita-citakan warga masyarakat dalam menyelesaikan sengketanya.

Beberapa contoh peran hakim dalam mewujudkan keadilan substansial atau keadilan yang dikehendaki para pencari keadilan (justiciabellen), sebagai upaya pemikiran hakim dalam menyelesaikan sengketa tidak hanya berpikir secara logika dan rasio, tetapi sudah berani mengembangkan pemikirannya. Putusan PTUN Semarang Nomor 04/G/2009/PTUN. SMG. Bahwa tugas hakim tidak hanya memutus sengketa berdasarkan undang-undang yang berlaku atau ada, menurut beliau undang-undang hanya dipergunakan sebagai pedoman saja. Dalam arti, hakim dapat menyimpang dari undang-undang, apalagi undang-undang tersebut tidak sesuai dengan rasa keadilan dan kemanfaatan dalam masyarakat (wawancara dengan hakim PTUN yogyakarta, kamis 13 Oktober 2011 dan hakim PTUN Semarang, Senin 10 Oktober 2011). Dalam kaitannya dengan kegiatan pertambangan daerah eksploitasi yang menimbulkan dampak besar dan penting terhadap lingkungan hidup wajib memiliki amdal, untuk memperoleh ijin melakukan usaha dan/atau kegiatan. Tidak dilengkapi dengan amdal tersebut, berarti tidak memperhatikan aspirasi masyarakat, yaitu masyarakat adat/samin atau sedulur sikep dan bertentangan dengan asasasas-asas umum pemerintahan yang baik, yaitu asas keterbukaan, kebijaksanaan, perlindungan atau pandangan hidup. Pertimbangan hakim Semarang dalam sengketa tersebut lebih mencerminkan atau mengedepankan nilai-nilai keadilan hukum dan rasa keadilan yang hidup dalam masyarakat, lebih memperhatikan kearifan lokal. Mereka berpendapat bahwa dengan beroperasinya pabrik semen di daerah Sukolilo akan merugikan kepentingan dan kebutuhan warga masyarakat terutama kaitannya dengan sumber mata air yang dipergunakan sebagai irigasi bagi petani. Pertanian di daerah tersebut merupakan mata pencaharian pokok.

Berdasarkan pemikiran hakim yang demikian tersebut dan kemudian dituangkan dalam pertimbangan hukum sebagai dasar putusannya, nampak peran hakim begitu penting dan bahkan sangat diharapkan serta dibutuhkan warga pencari keadilan. Pertimbangan hukum tersebut, di samping hakim berpikir dengan logika atau lq juga sudah menggunakan Sq dan eq. Intellectual quotient (Iq) belum menggambarkan atau mewakili cara berpikir manusia seluruhnya, oleh karena itu perlu dilengkapi dengan eq (emotional quotient), yaitu berpikir asosiatif atau berpikir dengan hati dan badan. Kemudian terakhir dengan Sq (Spiritual quotient) yang oleh Zohar dan Marshall dinobatkan sebagai intelegensi yang paling sempurna (ultimate intelligence) (Satjipto Rahardjo, 2007 : 93).

Putusan Nomor 81/G/2009/PTUN/SMG. Putusan tersebut tentang pemberhentian tidak dengan hormat sdr. Agus Riyanto sebagai perangkat Desa Klaling, kecamatan Jekulo, Kabupaten Kudus. Kepala Desa (lama) Haryadi diganti Sutrimo. Kepala Desa Sutrimo menghentikan Agus Riyanto dengan alasan melanggar Pasal 38 ayat (2) huruf b Perda, Kab. Kudus Nomor 20 Tahun 2006 jo. Pasal 58 ayat (2) huruf b Bupati Kudus Nomor 1 Tahun 2008. Dalam kasus tersebut, obyek sengketa harus dibatalkan karena penggugat (Agus Riyanto) tidak terbukti selama dua tahun enam bulan tidak masuk melaksanakan tugasnya. Penggugat masih mempunyai itikad baik untuk masuk menjalankan tugasnya, namun karena ada sintemen politik dengan Sutrimo, maka berakibat pada pemberhentian Agus R.

Putusan Nomor 03/G/2000/PTUN/ yK. Penggugat adalah Sumardiyono, ia diberhentikan dari jabatan Kepala Urusan Pemerintahan Desa Bangunharjo, Kec. Sewon, Kab. Dati II bantul. la diberhentikan karena melakukan perjudian, melanggar Pasal 
7 ayat (3) Keputusan Bupati Kepala Daerah Dati II Bantul Nomor 585/A/Kep/Bt/1996. Putusan PT yogyakarta Nomor 48/Pid/98/ PTy, menyatakan Sumardiyono secara sah dan meyakinkan bersalah melakukan tindak pidana, tanpa hak dengan sengaja memberi kesempatan kepada khalayak umum untuk melakukan permainan judi (pidana penjara tiga bulan 15 hari).

Peran hakim dalam kasus tersebut adalah bahwa keputusan tentang pemberhentian Sumardiyono tanpa mempertimbangkan kepentingan-kepentingan menurut nalar dan fakta relevan yang mempunyai kedudukan penting yang harus dipertimbangkan oleh tergugat (Bupati). Perbuatan tergugat bertentangan dengan asas-asas umum pemerintahan yang baik, yaitu asas kecermatan (tidak termasuk dalam asasasas umum pemerintahan yang baik sebagaimana disebut pada penjelasan Pasal 53 ayat (2) Undang-undang Nomor 9 Tahun 2004 tentang PTUN). Fakta tersebut jika dipertimbangkan pada waktu pengambilan keputusan atau beschikking, maka hakim mempunyai pandangan bahwa Sumardiyono tidak akan diberhentikan. Di samping hal tersebut, menurut hakim tergugat telah secara sewenang-wenang menerapkan sanksi yang tidak diperhitungkan keseimbangannya antara bobot pelanggaran yang dilakukan dengan hukuman yang dijatuhkan kepada penggugat atau Sumardiyono. Tergugat melanggar asas keseimbangan (tidak masuk pada penjelasan Pasal 53 ayat (2) UU PTUN). Hal tersebut dinilai tidak sesuai dengan nilai keadilan, maka majelis hakim memutuskan obyek sengketa dibatalkan. Perbuatan penggugat (berjudi) bukan sebagai mata pencaharian yang dilakukan sehari-hari, melainkan sebagai usaha mata-mata untuk mencari informasi sehubungan ada peristiwa pembunuhan di desanya.

Putusan Nomor 11/G/2010/PTUN/yk. Dwi Sukamto (penggugat) adalah salah satu bakal calon staf, telah melakukan seleksi bersama dengan yang lainnya. Dwi $S$ memperoleh nilai tertinggi (di antara sembilan peserta). Berdasarkan Perda Nomor 9 Tahun 2007, Kepala Desa menyampaikan permintaan persetujuan penetapan staf kepada BPD dengan dilampiri berita acara, namun BPD menolak untuk memberi persetujuan dengan Keputusan Nomor 04/
KeP/BPD/2010. Berdasarkan penolakan tersebut, Dwi Sukamto mengajukan gugatan ke PTUN yogyakarta.

Peran hakim dalam mewujudkan keadilan substansial adalah nampak pada pertimbangan hukum yang digunakan sebagai dasar putusannya, yaitu menyatakan tergugat di dalam menerbitkan obyek sengketa atau keputusan bertentangan dengan asas-asas umum pemerintahan yang baik terutama asas fair play (tidak termasuk yang disebut pada penjelasan Pasal 53 ayat (2) UU PTUN) dan tindakan tergugat dinilai oleh majelis hakim merupakan tindakan sewenangwenang. Hal tersebut diketahui bahwa tergugat di dalam menerbitkan keputusan tentang penolakan permintaan persetujuan penetapan Dwi Sukamto sebagai staf desa Kedungsari didasarkan pada rumor, dugaan atau indikasi, tanpa adanya pembuktian berdasarkan hukum. Kecurigaan tentang nilai yang diperoleh Dwi Sukamto (nilai 97 dan di bawahnya 66) berdasarkan pengaduan peserta lain tanpa dibuktikan lebih dahulu, ujian tidak dilaksanakan dengan transparan adalah tidak benar. Peran aktif hakim untuk mewujudkan keadilan substansial dapat dilihat pada putusan Nomor 10/G/2010/ PTUN/yk.

\section{d. Simpulan}

Hakim sebagai penegak hukum dan keadilan sudah saatnya untuk meninggalkan cara berhukum yang lama, yaitu cara-cara yang hanya mengandalkan atau mengedepankan ketentuanketentuan dalam peraturan perundang-undangan, secara mekanistik, dan hasilnya dapat diprediksi. Cara berhukum yang lama akan menghasilkan keadilan prosedural atau formal, keadilan yang berpihak pada penguasa. Hakim bukan lagi sebagai corong yang membunyikan ketentuanketentuan pasal undang-undang, bekerja terkungkung oleh kekauan undang-undang, dan lebih mengedepankan logika dengan pemikiran yang abstrak. Hakim dalam menyelesaikan sengketa tidak hanya mengandalkan logika dan rasio, berpikir hanya berdasarkan Iq, namun juga sudah berkembang atau bergeser ke arah pemikiran dengan Sq dan eq.

Hakim harus berani keluar dari belenggu undang-undang yang kaku, bersifat abstrak dan kurang akomodatif, berani melakukan terobosan, aktif, kreatif, berpandangan jauh ke depan, berani berijtihad untuk kebenaran 
dan keadilan sebagaimana diharapkan warga masyarakat. Hakim sebagai aktor yang penting dalam berhukum di pengadilan mempunyai kebebasan dan tidak terikat oleh campur tangan pihak lain. Sebelum menjatuhkan putusan, hakim mempunyai berbagai pertimbangan atau berbagai alternatif sebagai pilihan, sehingga putusan yang dijatuhkan mengandung keadilan yang bersifat substansial. Keadilan yang telah berakar di dalam kehidupan masyarakat, yang meliputi hak-hak sosial yang menandai penataan politik, ekonomi dalam masyarakat. Sebagaimana hukum yang baik adalah hukum yang tumbuh sebagai pencerminan masyarakat dan nilai-nilai yang hidup dalam masyarakat.

\section{E. Saran}

Hakim sebagai penegak hukum dan keadilan dalam menjatuhkan putusan tidak hanya terbelenggu oleh ketentuan undang-undang produk legislatif, tidak hanya mengedepankan logika dan rasio, berpikir linear, deterministik, hakim harus berani mengembangkan pemikirannya, keratif, ia harus berani melakukan terobosan untuk melihat hukum tidak tertulis yang hidup dalam masyarakat, agar putusan yang dihasilkan mencerminkan keadilan subtstantif sebagaimana dikehendaki masyarakat. Keberanian hakim sudah waktunya atau saatnya dilakukan, karena sesuai tuntutan dan perkembangan masyarakat yang semakin hari semakin kompleks.

\section{daftar Pustaka}

Abdullah. 2008. Pertimbangan hukum Putusan Pengadilan. Sidoarjo : Program Pascasarjana Universitas Sunan Giri.

Abdul Ghofur Anshori dan Sobirin Malian. 2008., Membangun hukum Indonesia. yogyakarta : Kreasi Total Media.

Achmad Ali. 2008. Menguak Tabir hukum. Bogor Selatan: Ghalia Indonesia.

Adi Sulistiyono. 2002. Mengembangkan Paradigma Penyelesaian Sengketa Non-litigasi dalam Rangka Pendayagunaan Alternatif Penyelesaian Sengketa Bisnis/hak Kekayaan Intelektual. Program Doktor Ilmu Hukum Universitas Diponegoro.

2006. Krisis Lembaga Peradilan di Indonesi. Surakarta: LPP UNS dan UNS Press.

Amin. 1952. Bertamasya ke Alam hukum. Jakarta : Fasco.

Anthon F. Susanto. 2005. Semiotika hukum dari Dekonstruksi Teks Menuju Progresivitas Makna. Bandung: Refika Aditama.

Antonius Sudirman. 2007. hati-Nurani hakim dan Putusannya Suatu Pendekatan dari Perspektif IImu hukum Perilaku (Behavioral Jurisprudence) Kasus Bismar Siregar. Bandung: Citra Aditya Bakti.

Carl Joachim Friendrich. 2004. Filsafat hukum Perspektif historis. Bandung: Nuansa dan Nusamedia.

George Ritzer, Sociology : A Multiple Paradigma Science, Penerjemah Alimandan. 1992. Sosiologi IImu Pengetahuan Berparadigma ganda. Jakarta: Raja Grafindo Persada.

Margaret M Poloma. 1994. Sosiologi Kontemporer, terjemahan tim penerbit Yosogama. Jakarta : Grafindo Persada.

Menski, Werner. 2006. comparative law in A global context, The Legal System of Asia and Afrika. United Kingdom : Cambridged University Press.

Munir Fuady. 2003. Aliran hukum Kritis (Paradigma Ketidakberdayaan hukum). Bandung : Citra Aditya Bakti. 2007. Dinamika Teori hukum. Bogor : Ghalia Indonesia.

Mulyana W. Kusumah. 1981. hukum, Keadilan dan hak Asasi Manusia, Suatu Pemahaman Kritis. Bandung: Alumni 
Prasetyo Hadi Purwandoko. 1996. Maret-Mei 1996. "Kebebasan Hakim dalam Mengadili Perkara Pelanggaran Lalu Lintas" Yustisia Nomor 35.

Riduan Syahrani. 2008. Rangkuman Intisari IImu hukum. Bandung: Citra Aditya Bakti.

Roihan A Rasyid. 2002. hukum Acara Peradilan Agama. Jakarta: Raja Grafindo Persada.

Satjipto Rahardjo. 2007. Biarkan hukum Mengalir catatan Kritis tentang Pergulatan Manusia dan hukum. Jakarta: Buku Kompas. 2008. Membedah hukum Progresif. Jakarta: Buku Kompas.

2009. Lapisan-lapisan hukum dalam Studi hukum. Malang : Bayumedia Publishing.

Sidharta. 2004. "Karateristik Penalaran Hukum dalam Konstek ke Indonesiaan." Bandung: Disertasi Program Ilmu Hukum Parahyangan.

Siti Malikhatun Badriyah. 2010. Penemuan hukum dalam Konteks Pencarian Keadilan. Semarang: Universitas Diponegoro.

Sudikno Mertokusumo. 2010. Penemuan hukum. yogyakarta : Universitas Atma Jaya.

1998. hukum Acara Perdata Indonesia. yogyakarta: Liberty.

Sudikno Mertokusumo dan A.Pitlo. 1993. Bab-bab Tentang Penemuan hukum. Bandung : Citra Aditya Bakti. Soerjono Soekanto. 1986. Pengantar Penelitian hukum. Jakarta : UI Press.

Tanya, Bernard L. yoan N. Simanjuntak, Markus y. Hage. 2010. Teori hukum Strategi Tertib Manusia Lintas Ruang dan generasi. yogyakarta: Genta Publishing.

Tamanaha, Brian Z. 2006. A general Jurisprudence of Law and Society. New york: Oxford University Press. http//www, hamline.edu/apakabar/basisdata/1996. 